\title{
INTRODUCTION
}

\section{Innovative use of sclerochronology in marine resource management}

\author{
Ewan Hunter ${ }^{1,2, *}$, Vladimir V. Laptikhovsky ${ }^{1}$, Philip R. Hollyman ${ }^{3,4}$ \\ ${ }^{1}$ Centre for Environment, Fisheries and Aquaculture Science, Lowestoft Laboratory, Lowestoft, Suffolk NR33 0HT, UK \\ ${ }^{2}$ School of Environmental Sciences, University of East Anglia, Norwich Research Park, Norwich NR4 7TJ, UK \\ ${ }^{3}$ School of Ocean Sciences, College of Natural Sciences, Bangor, Menai Bridge, Anglesey LL59 5AB, UK \\ ${ }^{4}$ Present address: British Antarctic Survey, High Cross, Madingley Rd, Cambridge CB3 0ET, UK
}

\begin{abstract}
In recent years, technical and analytical developments in sclerochronology, based on the analysis of accretionary hard tissues, have improved our ability to assess the life histories of a wide range of marine organisms. This Theme Section on the innovative use of sclerochronology was motivated by the cross-disciplinary session 'Looking backwards to move ahead - how the wider application of new technologies to interpret scale, otolith, statolith and other biomineralised age-registering structures could improve management of natural resources' convened at the 2016 ICES Annual Science Conference in Riga, Latvia. The contributions to this Theme Section provide examples of applications to improve the assessment and management of populations and habitats, or showcase the potential for sclerochronology to provide a deeper understanding of the interaction between marine life and its environment, including the effects of changing climate.
\end{abstract}

KEY WORDS: Sclerochronology · Otoliths · Statoliths - Scales · Beaks · Life-histories · Ageing · Fisheries management

\section{INTRODUCTION}

In recent years, insights gained from sclerochronology-based studies, primarily obtained through isotopic and trace element analyses of age-registering accretionary hard tissues, have contributed significantly to understanding the life-history biology of marine organisms, and the assessment and management of populations and habitats (Arkhipkin 2005, Geffen et al. 2016, Grønkjær 2016, Tanner et al. 2016, Tzadik et al. 2017). Beyond single species and niche analyses, sclerochronology has provided a deeper understanding of the interaction between marine life and its environment, including the effects of changing climate (Morrongiello et al. 2012, Ong et al. 2016, 2018). At a time of worldwide funding constraints in applied science (UNESCO 2017), sclerochronological analyses of existing time-series sample collections are a comparatively affordable way of data mining.

\footnotetext{
${ }^{*}$ Corresponding author: ewan.hunter@cefas.co.uk
}

The combined analysis of historical and new data allows insights into past marine environmental conditions that can inform future decision-making in fisheries management and environmental sciences.

At the 2016 ICES Annual Science Conference in Riga, Latvia, the session 'Looking backwards to move ahead-how the wider application of new technologies to interpret scale, otolith, statolith and other biomineralised age-registering structures could improve management of natural resources' (ICES 2016) was held to broaden understanding, expedite crossfertilisation between different but related areas of sclerochronology, and facilitate the wider uptake of state-of-the-art approaches. The session attendees aimed to address assessment and management applications, from species-specific ageing methods and migration studies to analytical stock assessments, using data collected with novel techniques. The crossdisciplinary session was intended to include technical

(C) The authors 2018. Open Access under Creative Commons by Attribution Licence. Use, distribution and reproduction are unrestricted. Authors and original publication must be credited. 
and ecological studies emphasising new methods and approaches to ageing and the use of aging data in a broad range of species and taxa. This resultant Theme Section presents a selection of papers either presented at, or representative of, the session at the 2016 ICES meeting. Held over 2 days, we attracted 43 contributions from 34 institutes (across 17 countries), over half of which were fish-centred, most focussing on aspects of otolith science.

\section{INNOVATIVE USE OF SCLEROCHRONOLOGY}

Otolith chemistry remains a driving force in fish population dynamics studies (e.g. Sturrock et al. 2012, Tanner et al. 2016, Izzo et al. 2018). The potential of sulphur isotopes $\left(\delta^{34} \mathrm{~S}\right)$ as biogeochemical markers in fish was examined by Doubleday et al. (2018 in this Theme Section), who provided evidence suggesting that otolith $\delta^{34} \mathrm{~S}$ concentrations recorded by juvenile tank-grown barramundi were influenced by both ambient water and diet. Underlining the importance of validating chemical signatures observed in the otoliths of wild fishes, Darnaude \& Hunter (2018 in this Theme Section) explored spatial and temporal variability in the acuity of otolith $\delta^{18} \mathrm{O}$ for providing fishery-independent estimates of fish location, by comparing the ambient environmental experience of North Sea plaice Pleuronectes platessa achival tags with $\delta^{18} \mathrm{O}$ recorded simultaneously in the otoliths from the same fish. Schilling et al. (2018 in this Theme Section) combined adult otolith elemental signatures with length frequency data of trawled fish to identify facultative estuary use by juvenile bluefish Pomatomus saltatrix in eastern Australia.

Otoliths are also instrumental in gauging the relative importance of, and interaction between, natural and anthropogenic drivers in shaping marine systems (e.g. Morrongiello et al. 2012, Black et al. 2016, Ong et al. 2016). Barrow et al. (2018 in this Theme Section) recreated a 32 yr growth history of rock flathead Platycephalus laevigatus and related growth variation to changes in freshwater flows, temperature, wind, and the Southern Oscillation Index. By disentangling the drivers of long-term growth variation in harvested fishes, future productivity under a range of environmental and management scenarios can be predicted. Fisher \& Hunter (2018 in this Theme Section) reviewed digital imaging techniques in otolith data capture, analysis and interpretation, and considered why computer-assisted age and growth estimation systems have yet to be adopted more widely. Other otolith work presented in the session but not included in the Theme Section comprised examples of incremental analysis and morphometrics, pollution monitoring, and chemical marking to assess the effectiveness of artificial restocking.

Otoliths remain the focus for most fish ageing research; however, fish chemical archives beyond otoliths are also important (Tzadik et al. 2017), notably non-lethal sampling strategies for rare, endangered, and long-lived fishes. Seeley \& Walther (2018 in this Theme Section) successfully applied inorganic and organic proxies to reconstruct migration and dietary histories from scales of the Atlantic tarpon Megalops atlanticus, demonstrating transhaline migrations associated with ontogenetic trophic shifts. With scale architecture facilitating sequential sub-sampling, this approach is an encouraging example of a non-lethal natural tag with clear fisheries management applications and citizen-science engagement opportunities.

The non-fish contributions to our meeting were almost exclusively molluscan (cephalopod, gastropod and bivalve ageing, and biochronology studies), reflecting the increasing scale and commercial importance of cephalopod and shellfish fisheries (Anderson et al. 2011, Doubleday et al. 2016). Until recently, squid have been aged primarily from statolith growth increments. Daily periodicity in increment formation is well established, but is related to diurnal feeding patterns rather than diurnal environmental cycles (Boyle \& Rodhouse 2005), so periodic starvation can potentially bias age readings. The 'chalky' statoliths of octopods, by contrast, have no discernible growth increments, and those of adult cuttlefish are subject to crystallization, so direct ageing of these cephalopods has not been possible until recently (except for juvenile and immature Sepia officinalis; Bettencourt \& Guerra 2000, 2001). Perales-Raya et al. (2018 in this Theme Section) compared the growth rates of naturally occurring and cultured octopus Octopus vulgaris paralarvae reared under different temperature and dietary regimes. In demonstrating the ageing potential of daily beak increments, a better understanding of the spatial dynamics of naturally occurring octopus paralarvae was also achieved.

Gastropod stock assessments have long posed difficulties due to key components of population dynamics, such as natural mortality and growth rate, remaining immeasurable. Hollyman et al. (2018 in this Theme Section) described the development and validation of statolith-based age determination in the commercially valuable whelk Buccinum undatum, combining field, laboratory and geochemical experiments to confirm an annual periodicity to visible 
growth increments within statoliths. Natural mortality estimates and population age structures will now allow fisheries scientists to perform analytical whelk stock assessments for the first time.

The biomineralised materials derived from marine organisms can also play a role in estimating rates of natural and fishing mortality in studies of population dynamics. In a study spanning marine biology, palaeontology and zoo-archeology, Laptikhovsky et al. (2018 in this Theme Section) reviewed existing methods to evaluate applying ageing analyses to collected dead material from a range of species groups (corals, molluscs, fish and marine mammals). The application of chemical and sclerochronological analyses are discussed for key structures such as mollusc shells, coral skeletons and fish otoliths often found in thanatocoenoses. Although not all approaches and techniques are transferrable due to diverse ecology and morphology, it is suggested that cross-fertilisation amongst the methods presented could yield new approaches for population dynamics studies.

\section{CONCLUSIONS}

The 9 papers presented in this Theme Section provide a representative rather than fully exhaustive cross-section of current state-of-the art sclerochronology applications. The use of elemental and isotopic analyses in determining life-history events and population structure continues to blossom; however, an underlying lack of understanding of both sampling protocols and underlying chemistry can only be addressed through more fundamental experimental studies. Cephalopod and gastropod ageing have yet to reach the same level of maturity as fish ageing studies. A wider uptake of the results of studies using biogeochemical markers into fisheries management should help to fuel this research area. We conclude that while sclerochronological techniques continue to improve and proliferate, there is still some way to go before the full realisation of potential in this field.

Acknowledgements. We thank Yves Cherel, Stylianos Somarakis and Stephen Wing for their professional handling of the review process.

\section{LITERATURE CITED}

Anderson SC, Flemming JM, Watson R, Lotze HK (2011) Rapid global expansion of invertebrate fisheries: trends, drivers, and ecosystem effects. PLOS ONE 6:e14735

Arkhipkin AI (2005) Statoliths as 'black boxes' (life recorders) in squid. Mar Freshw Res 56:573-583
Barrow J, Ford J, Day R, Morrongiello J (2018) Environmental drivers of growth and predicted effects of climate change on a commercially important fish, Platycephalus laevigatus. Mar Ecol Prog Ser 598:201-212

Bettencourt V, Guerra A (2000) Growth increments and biomineralization process in cephalopod statoliths. J Exp Mar Biol Ecol 248:191-205

Bettencourt V, Guerra A (2001) Age studies based on daily growth increments in statoliths and growth lamellae in cuttlebone of cultured Sepia officinalis. Mar Biol 139: 327-334

Black BA, Griffin D, Sleen P, Wanamaker AD and others (2016) The value of crossdating to retain high-frequency variability, climate signals, and extreme events in environmental proxies. Glob Change Biol 22:2582-2595

Boyle PR, Rodhouse P (2005) Cephalopods: ecology and fisheries. Blackwell Science, Oxford

Darnaude AM, Hunter E (2018) Validation of otolith $\delta^{18} \mathrm{O}$ values as effective natural tags for shelf-scale geolocation of migrating fish. Mar Ecol Prog Ser 598:167-185

* Doubleday ZA, Prowse TAA, Arkhipkin A, Pierce GJ and others (2016) Global proliferation of cephalopods. Curr Biol 26:R406-R407

Doubleday ZA, Cliff J, Izzo C, Gillanders BM (2018) Untapping the potential of sulfur isotope analysis in biominerals. Mar Ecol Prog Ser 598:159-166

*Fisher M, Hunter E (2018) Digital imaging techniques in otolith data capture, analysis and interpretation. Mar Ecol Prog Ser 598:213-231

*Geffen AJ, Morales-Nin B, Gillanders BM (2016) Fish otoliths as indicators in ecosystem based management: results of the 5th International Otolith Symposium (IOS2014). Mar Freshw Res 67:i-iv

*Grønkjær P (2016) Otoliths as individual indicators: a reappraisal of the link between fish physiology and otolith characteristics. Mar Freshw Res 67:881-888

*Hollyman PR, Leng MJ, Chenery SRN, Laptikhovsky VV, Richardson CA (2018) Statoliths of the whelk Buccinum undatum: a novel age determination tool. Mar Ecol Prog Ser 598:261-271

ICES (2016) Theme session H. Looking backwards to move ahead-how the wider application of new technologies to interpret scale, otolith, statolith and other biomineralised age-registering structures could improve management of natural resources [Theme Session Report]. Hunter E, Laptikhovsky V, Hollyman P (convenors). ICES, Copenhagen. www.ices.dk/news-and-events/asc/ ASC2016/Documents/Theme\%20session\%20reports/ Theme $\% 20$ session $\% 20$ H.pdf

* Izzo C, Reis-Santos P, Gillanders BM (2018) Otolith chemistry does not just reflect environmental conditions: a meta-analytic evaluation. Fish Fish, doi:10.1111/faf.12264

Laptikhovsky VV, Barrett CJ, Hollyman PR (2018) From coral reefs to whale teeth: estimating mortality from natural accumulations of skeletal materials. Mar Ecol Prog Ser 598:273-291

Morrongiello JR, Thresher RE, Smith DC (2012) Aquatic biochronologies and climate change. Nat Clim Chang 2: 849-857

* Ong JJL, O'Donnell AJ, Meeuwig JJ, Zinke J and others (2016) Evidence for climate-driven synchrony of marine and terrestrial ecosystems in northwest Australia. Glob Change Biol 22:2776-2786

* Ong JJL, Rountrey A, Black BA, Nguyen HM and others (2018) A boundary current drives synchronous growth of 
marine fishes across tropical and temperate latitudes. Glob Change Biol, doi:10.1111/gbc.14083

Perales-Raya C, Nande M, Roura A, Bartolomé A and others (2018) Comparative study of age estimation in wild and cultured Octopus vulgaris paralarvae: effect of temperature and diet. Mar Ecol Prog Ser 598:247-259

Schilling HT, Reis-Santos P, Hughes JM, Smith JA and others (2018) Evaluating estuarine nursery use and life history patterns of Pomatomus saltatrix in eastern Australia. Mar Ecol Prog Ser 598:187-199

Seeley ME, Walther BD (2018) Facultative oligohaline habitat use in a mobile fish inferred from scale chemistry. Mar Ecol Prog Ser 598:233-245

Sturrock AM, Trueman CN, Darnaude AM, Hunter E (2012)
Can otolith elemental chemistry retrospectively track migrations in fully marine fishes? J Fish Biol 81:766-795

Tanner SE, Reis-Santos P, Cabral HN (2016) Otolith chemistry in stock delineation: a brief overview, current challenges and future prospects. Fish Res 173:206-213

Tzadik OE, Curtis JS, Granneman JE, Kurth BN and others (2017) Chemical archives in fishes beyond otoliths: a review on the use of other body parts as chronological recorders of microchemical constituents for expanding interpretations of environmental, ecological, and life history changes. Limnol Oceanogr Methods 15:238-263

UNESCO (2017), Global Ocean Science Report-the current status of ocean science around the world. UNESCO, Paris 